\title{
KAOLINITISASI DAN MOBILITAS UNSUR TANAH JARANG PADA PROFIL PELAPUKAN BATUAN GUNUNGAPI DI PUNCAK MANDEH, SUMATRA BARAT
}

\section{KAOLINITIZATION AND RARE EARTH ELEMENTS MOBILIZATION OF A VOLCANIC ROCK WEATHERING PROFILE IN PUNCAK MANDEH, WEST SUMATRA}

\author{
Ronaldo Irzon, Kurnia, Purnama Sendjaja, dan Verry E. Setiawan \\ Pusat Survei Geologi \\ ronaldoirzon18@gmail.com
}

\begin{abstract}
ABSTRAK
Proses pelapukan berlangsung di permukaan bumi terutama pada wilayah beriklim tropis dan menyebabkan mobilisasi elemen dari batuan induk. Pelapukan menarik untuk dipelajari karena seringkali dikaitkan dengan pengayaan bahan-bahan ekonomis seperti besi, alumina, dan UTJ. Profil pelapukan batuan gunungapi Tersier tersebar di Sumatra yang beriklim tropis. Studi ini bertujuan untuk menjabarkan proses kaolinitisasi dan proses mobilisasi UTJ pada profil pelapukan batuan gunungapi di timur Puncak Mandeh, Sumatra Barat. Perangkat XRF dan ICP-MS dimanfaatkan untuk mengukur kelimpahan oksida utama, unsur jejak, dan UTJ. Kenaikan IOL terbukti terjadi searah dengan tingkat pelapukan. Kaolinitisasi pada pelapukan di Puncak Mandeh ditunjukkan oleh diagram segitiga $\mathrm{SiO}_{2}-\mathrm{Al}_{2} \mathrm{O}_{3}-\mathrm{Fe}_{2} \mathrm{O}_{3}$. Feldspar dan mika yang rentan terhadap pelapukan langsung berubah menjadi kaolinit pada tahap awal pelapukan untuk menjelaskan variasi oksida utama pada profil pelapukan. Proses pelapukan telah meningkatkan jumlah alumina dan besi secara signifikan relatif terhadap batuan induk. Tidak terdapat pengayaan UTJ pada horizon pelapukan dibandingkan dengan komposisinya pada batuan induk. Sebagian Ce teroksidasi menjadi $\mathrm{Ce}^{4+}$ dan tertinggal di horizon saprolit. Kondisi ini membuat mobilitas Ce yang searah tingkat pelapukan berbeda dengan unsur UTJ lainnya.
\end{abstract}

Kata kunci: batuan gunungapi, kaolinitisasi, pelapukan, UTJ

\section{ABSTRACT}

The weathering process occurs on the Earth's surface, especially in tropical climates, and causes the parent rock's mobilization of elements. Weathering is interesting because it is often associated with the enrichment of economic materials such as iron, alumina, and REEs. The weathering profile of Tertiary volcanic rocks is spread across tropical Sumatra. This study aims to describe REEs' kaolinization and mobilization process on the weathering profile of volcanic rocks in the east of Mandeh Peak, West Sumatra. XRF and ICP-MS devices are utilized to measure the abundance of major oxides, trace elements, and REEs. The increase in IOL is proven to occur in the same direction as weathering levels. A triangular diagram of $\mathrm{SiO}_{2}-\mathrm{Al}_{2} \mathrm{O}_{3^{-}}$ $\mathrm{Fe}_{2} \mathrm{O}_{3 \mathrm{~T}}$ indicates kaolinization on weathering at Mandeh Peak. Feldspar and mica were prone to weathering and instantly turn into kaolinite in the early stages of weathering to explain the main oxide variations in weathering profiles. The weathering process has increased the amount of alumina and iron significantly relative to the parent rock. There is no REEs enrichment on any of the weathering horizons other than its composition on the parent rocks. Part of $\mathrm{Ce}$ is oxidized into $\mathrm{Ce}^{4+}$ and left on the saprolite horizon. This condition makes Ce's mobility in the direction of weathering level is different from other REEs.

Keywords: kaolinitization, REE, volcanic rock, weathering 


\section{PENDAHULUAN}

Pelapukan adalah proses dekomposisi batuan maupun mineral di permukaan bumi. Proses ini mudah ditemukan di berbagai wilayah dengan bermacam jenis batuan induk dan dapat dimanfaatkan untuk menjelaskan kondisi lingkungan pada masa lampau (Fernández-Caliani dan Cantano, 2010; Bazilevskaya dkk., 2013; Sahoo dkk., 2017; Fernández-Caliani, 2018). Mekanisme ini lebih rentan terjadi pada wilayah tropis akibat adanya derajat kelembaban tinggi dan siklus hujan sepanjang tahun (Fernández-Caliani, 2018; Permanajati dkk., 2018; Meshram dkk., 2019). Selain iklim, intensitas pelapukan juga dipengaruhi oleh beberapa faktor lain, seperti umur, struktur, tekstur, distribusi pori, permeabilitas dan komposisi batuan induk (Alam dkk., 2012; Labus dan Bochen, 2012; Bazilevskaya dkk.,2013; Garzanti dkk., 2014; Irzon dan Abdullah, 2018). Pada umumnya, suatu profil pelapukan dapat dibagi menjadi beberapa horizon dari bawah ke atas searah pelapukan, yaitu batuan induk, saprolit, laterit, dan soil (Gambar 1). Lebih lanjut, profil pelapukan dapat diklasifikasi menjadi lebih banyak horizon berdasarkan ragam kenampakan megaskopisnya di lapangan (Fernández-Caliani, 2018; Ohandja dkk., 2020; Tupaz dkk., 2020).

Ragam mineral sekunder seperti oksida besi, bauksit, dan kaolinit lazim terjadi akibat pelapukan mineral kaya besi, mineral berkadar alumina tinggi, dan $\mathrm{K}$ felspar secara berurutan (Abedini dan Calagari, 2016). Oleh sebab itu, terdapat mobilisasi unsur yang berasosiasi terhadap proses pelapukan karena pembentukan mineral sekunder tersebut. Meskipun pada awalnya Unsur Tanah Jarang (UTJ) dianggap resisten terhadap alterasi, kelompok unsur ini justru dapat terkayakan pada mineral sekunder yang berasosiasi dengan pelapukan seperti monasit, cerianit, alanit, dan xenotim (Du dkk., 2012; Abedini dan Calagari, 2016; FernándezCaliani, 2018; dos Santos dkk., 2019). Fakta tersebut mendorong penelitian selanjutnya hingga ditemukan deposit unsur tanah jarang (UTJ) tipe ionadsorption pada beberapa wilayah Asia Tenggara (Yussof dkk., 2013; Sanematsu dkk., 2015; Handoko dan Sanjaya, 2018; Yaraghi dkk., 2020). Penelitian-penelitian tersebut menyimpulkan bahwa terdapat kemungkinan pengayaan jumlah UTJ pada horizon pelapukan tertentu dibandingkan dengan batuan induknya.

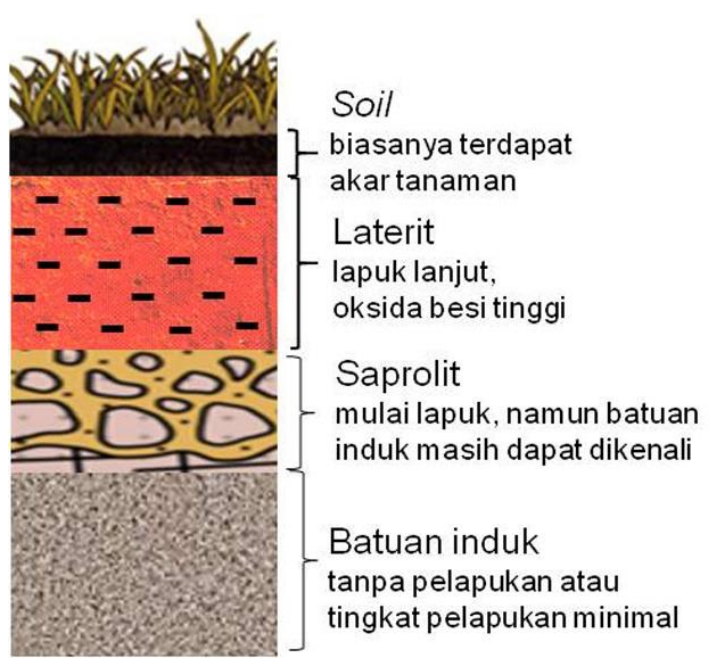

Gambar 1. Beberapa horizon yang secara umum terdapat pada suatu profil pelapukan batuan (modifikasi dari Irzon dkk. (2016))

Wilayah Sumatra kini adalah hasil amalgamasi Lempeng West Sumatra yang merupakan pecahan dari Cathaysia dan barat Lempeng Sibumasu yang berasal dari Gondwana (Metcalfe, 2017; Irzon dkk., 2020). Bagian dari Sumatra yang merupakan wilayah West Sumatra dan Sibumasu dipisahkan oleh garis imajiner yang disebut Medial Sumatra Tectonic Zone (MSTZ). Batuan tertua yang tersingkap di Sumatra diperkirakan berumur Paleozoikum dan terdiri dari batuan metamorfik maupun batuan intrusif. Kedua jenis batuan tersebut terus terbentuk hinggga zaman Kuarter dan melibatkan beberapa lempeng samudra maupun benua, yaitu Palaeo-Tethys, Meso-Tethys, India-Australia, West Sumatra, dan Sibumasu. Jajaran Bukit Barisan terbentuk akibat penunjaman Lempeng Samudra India-Australia ke bawah Lempeng West Sumatra sejak periode Eosen (Zulkarnain, 2016; Liu dkk., 
2019). Penunjaman tersebut masih berlangsung hingga kini dengan rerata kecepatan 5,7 cm/tahun (Liu dkk., 2019).

Pulau Sumatra dilintasi oleh ekuator dan merupakan pulau terbesar ke-6 di dunia. Seluruh wilayah Sumatra berada tidak jauh dari garis ekuator sehingga beriklim tropis yang sangat rentan terhadap pelapukan. Penelitian mengenai korelasi pelapukan terhadap perubahan komposisi batuan pada pulau-pulau di bagian timur Sumatra telah dibahas (Irzon dkk., 2016; Irvani, 2017). Kelimpahan UTJ pada horizon laterit di Kabupaten Singkep terkayakan hingga lebih dari empat kali lipat daripada batuan induknya (Irzon dkk., 2016). Bauksitisasi di Pulau Selayar adalah hasil pelapukan batuan kaya alumina dengan kandungan $\mathrm{Al}_{2} \mathrm{O}_{3}$ dan $\mathrm{Fe}_{2} \mathrm{O}_{3 \mathrm{~T}}$ tertinggi mencapai masing-masing $37,39 \%$ dan $23,84 \%$ secara berurutan (Irzon, 2018). Namun demikian, belum ada penelitian yang menjelaskan dampak pelapukan terhadap mobilisasi UTJ di bagian barat Pulau Sumatra, terutama di wilayah Sumatra Barat. Di wilayah Puncak Mandeh, Kabupaten Pesisir Selatan, Sumatra Barat terdapat singkapan batuan gunungapi, batuan intrusi, dan endapan permukaan. Profil-profil pelapukan dari batuan gunungapi dapat dijumpai di sisi jalan raya pada daerah yang berada di Provinsi Sumatra Barat ini. Studi ini bertujuan untuk menjabarkan proses kaolinitisasi dan proses mobilisasi UTJ pada profil pelapukan batuan gunungapi di timur Puncak Mandeh.

\section{METODOLOGI}

Penelitian ini terdiri dari lima sampel yang diperoleh dari suatu profil pelapukan batuan gunungapi yang meliputi batuan induk, horizon saprolit, horizon laterit bawah, horizon laterit atas, dan soil (Gambar 2a). Setiap sampel diambil secara berhati-hati karena garis batas antar horizon tidak merata. Batuan induk (tebal $\approx 40 \mathrm{~cm}$ ) diperkirakan berkomposisi andesit hingga dasit, keabuan, kuat, keras dan pejal (Gambar 2b). Meskipun sudah mengalami pelapukan tingkat menengah, karakter batuan induk masih dapat terlihat secara megaskopis pada sampel dari horizon saprolit dengan rerata ketebalan sekitar 50 $\mathrm{cm}$ (Gambar 2c). Karena terdapat perbedaan kontras secara megaskopis, horizon laterit dapat diklasifikasi menjadi dua lapisan. Horizon laterit bawah (tebal hampir $1 \mathrm{~m}$ ) berwarna merah lebih pucat daripada horizon laterit atas $(50 \mathrm{~cm})$. Selain itu, beberapa kerikilan batuan beku lapuk lanjut masih dapat dijumpai pada horizon laterit bawah (Gambar 2d) sedangkan sampel dari horizon atas relatif tanpa material tersebut (Gambar 2e). Masih terdapat akar tetumbuhan pada horizon soil yang berwarna gelap. Horizon paling atas ini memiliki ketebalan sekitar $20 \mathrm{~cm}$.

Setelah pencatatan mengenai kondisi profil singkapan berikut kondisi dan deskripsi setiap sampel, material studi dikirim ke Pusat Survei Geologi di Bandung untuk diperiksa kandungan geokimianya menggunakan X-Ray Fluorescence (XRF) dan Inductively Coupled Plasma - Mass Spectrometry (ICP-MS). Perangkat pertama digunakan untuk mengetahui kandungan oksida utama, yaitu $\mathrm{SiO}_{2}, \mathrm{TiO}_{2}, \mathrm{Al}_{2} \mathrm{O}_{3}$, $\mathrm{Fe}_{2} \mathrm{O}_{3 \mathrm{~T}}, \mathrm{CaO}, \mathrm{MgO}, \mathrm{MnO}, \mathrm{K}_{2} \mathrm{O}, \mathrm{Na}_{2} \mathrm{O}$, dan $\mathrm{P}_{2} \mathrm{O}_{5}$. Pada sisi lain, konsentrasi unsur jejak maupun UTJ (Li, Sc, V, Ga, Rb, Sr, Y, Nb, $\mathrm{Ba}$, La, Ce, Pr, Nd, Sm, Eu, Gd, Tb, Dy, Ho, $\mathrm{Er}, \mathrm{Tm}, \mathrm{Yb}, \mathrm{Lu}, \mathrm{Ta}$, Th, dan U) diukur menggunakan ICP-MS. Batuan induk dicuci dan dipisahkan dari bagian-bagian lapuk pada tepiannya sebelum digerus hingga didapatkan besar butir -200 mesh. Pada sisi lain, sampel lain tidak melalui proses pencucian sehingga langsung ke tahap penggerusan.

Metode pressed pellet dipilih dan dipergunakan untuk analisis XRF dalam studi ini dengan runtunan yang dijelaskan oleh Irzon dkk. (2018). Teknik destruksi menggunakan tiga jenis asam, yaitu asam klorida $(\mathrm{HCl})$, asam nitrat $\left(\mathrm{HNO}_{3}\right)$, dan asam format (HF) diaplikasikan sebelum pengukuran menggunakan ICP-MS seperti dijelaskan oleh Irzon dkk. (2020). Sampel berikut larutan asam direaksikan dalam cawan Teflon dan dipanaskan di atas hotplate untuk mempercepat destruksi. 


\section{MAKALAH ILMIAH}

Penambahan asam perklorat tidak dibutuhkan karena seluruh sampel tampak terlarut sempurna tepat sesaat sebelum seluruh larutan mengering. Asam nitrat 2\% ditambahkan ke dalam cawan Teflon berisi sampel untuk membuat larutan induk yang kemudian diencerkan lebih lanjut pada hari pengujian dengan ICP-MS. Kualitas

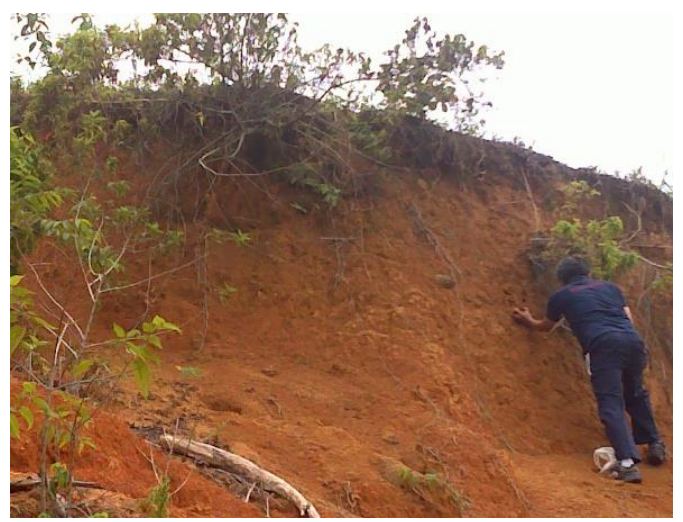

(a)

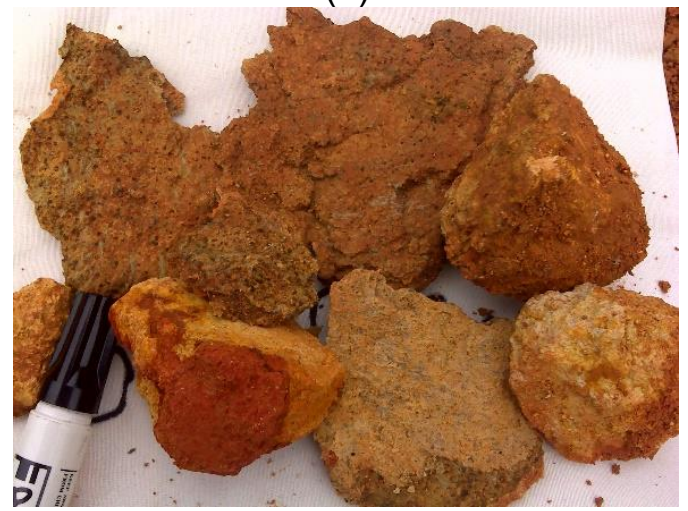

(c) pengukuran yang baik diperlukan agar didapatkan interpretasi yang baik, salah satunya adalah dengan pengujian Certified Standard Material (CRM). Oleh sebab itu, dua buah CRM (AGV-2 dan GBW-7113) turut dianalisis dalam studi ini untuk mengetahui akurasi pengukuran.

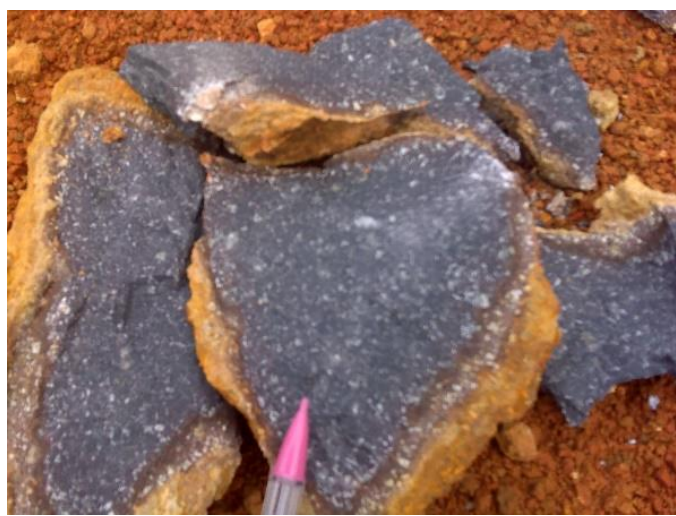

(b)

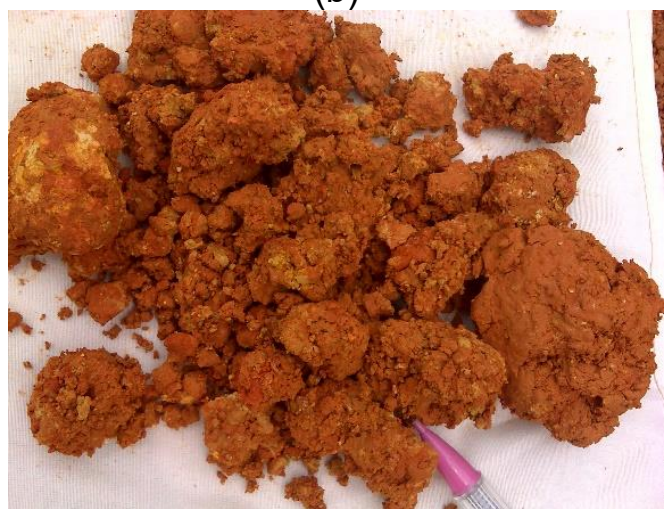

(d)

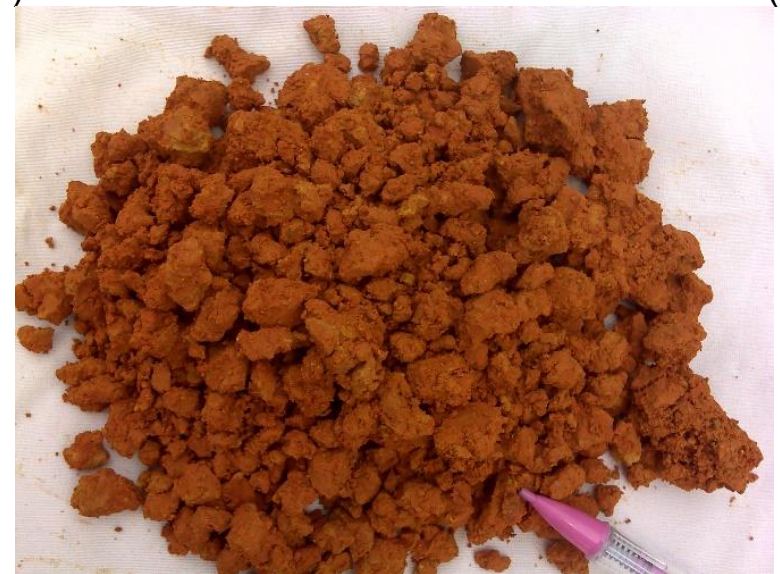

(e)

Gambar 2. Kondisi lapangan profil pelapukan dan sampel yang dipelajari: a) profil singkapan secara umum yang berlokasi di timur Puncak Mandeh; b) batuan induk yang diperkirakan bekomposisi andesit-dasit; c) bongkah-bongkah yang mirip batuan induk pada horizon saprolit; d) sampel dari bagian bawah horizon laterit dengan warna merah pucat; e) sampel dari horizon laterit atas berwarna merah gelap 
Terdapat beragam metoda kalkulasi untuk menentukan derajat pelapukan batuan, seperti CIA (Chemical Index of Alteration), PIA (Plagioclase Index of Alteration), CALMAG (flux of calcium and magnesium), dan IOL (Index of Lateritization). Metode IOL telah digunakan pada studi sebelumnya dalam mempelajari profil pelapukan batuan (Babechuk dkk., 2014; Sahoo dkk., 2017; Ohandja dkk., 2020; Tupaz dkk., 2020) dan diadaptasi dalam studi ini untuk dapat membandingkan tingkat pelapukan setiap horizon. IOL berbasis pada tiga oksida utama $\left(\mathrm{SiO}_{2}, \mathrm{Al}_{2} \mathrm{O}_{3}\right.$, dan $\left.\mathrm{Fe}_{2} \mathrm{O}_{3} \mathrm{~T}\right)$ dan dikalkulasi berdasarkan persamaan (1) berikut:

$\mathrm{IOL}=100 \times\left(\left(\mathrm{Al}_{2} \mathrm{O}_{3}+\mathrm{Fe}_{2} \mathrm{O}_{3 \mathrm{~T}}\right) /\left(\mathrm{SiO}_{2}+\mathrm{Al}_{2} \mathrm{O}_{3}\right.\right.$ $\left.\left.\left.+\mathrm{Fe}_{2} \mathrm{O}_{3 \mathrm{~T}}\right)\right) \ldots \ldots . .1\right)$

\section{GEOLOGI}

Daerah penelitian berada di utara dari Peta Geologi Lembar Painan dan Bagian Timurlaut Lembar Muara Siberut berskala 1:250.000 (Rosidi dkk., 1996). Terdapat empat satuan batuan yang berada di sekitar wilayah studi, yaitu Ultrabasa, Granit, Batuan Gunungapi Oligo-Miosen, dan Aluvium. Batuan Ultrabasa diperkirakan terbentuk pada zaman Kapur dan disimpulkan sebagai batuan yang tertua di sekitar Kabupaten Painan. Satuan batuan tersebut diduga bersentuhan dengan batuan Paleozoikum dan terdiri dari diabas yang terserpentinisasi, serpentinit, maupun harzburgit. Sesuai dengan namanya, Batuan Gunungapi Oligo-Miosen terbentuk pada kala Oligosen AKhir hingga Miosen Awal. Profil yang diteliti merupakan hasil pelapukan batuan gunungapi ini. Satuan Batuan Gunungapi Oligo-Miosen tersingkap pada sebagian besar daerah penelitian dan terdiri dari lava, breksi, tuf, dan ignimbrit. Granit di Painan yang terdiri dari ganit hornblenda sampai granodiorit terbentuk pada zaman Tersier. Batuan intrusif tersebut menerobos Formasi Barisan (tidak terdapat di sekitar wilayah penelitian) dan Batuan Gunungapi Oligo-Miosen (Rosidi dkk., 1996). Lanau, pasir, dan kerikil membentuk endapan aluvium pada zaman Kuarter (Gambar 3).

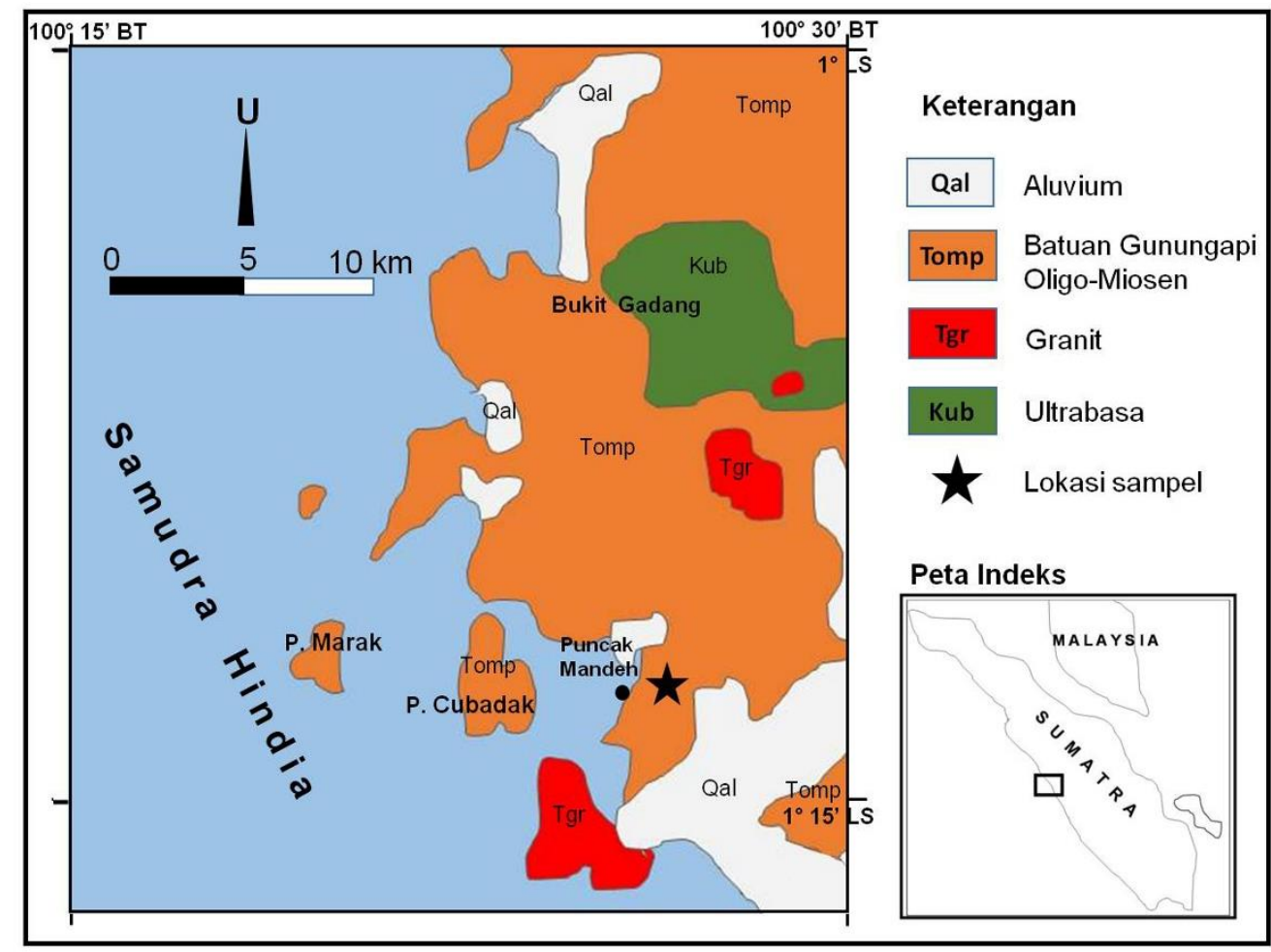

Gambar 3. Geologi regional wilayah Kabupaten Pesisir Selatan (Rosidi dkk., 1996). Profil yang diteliti dalam studi sebagai pelapukan batuan gunungapi berumur Oligo-Miosen 


\section{MAKALAH ILMIAH}

\section{HASIL DAN PEMBAHASAN}

Batuan induk dapat dikelompokkan dalam batuan beku intermediate dengan kadar $\mathrm{SiO}_{2} 66,24 \%$. Kelimpahan oksida alumina dan besi pada batuan tersebut dikategorikan menengah, yaitu masingmasing $15,77 \%$ dan $5,24 \%$ secara berurutan (Tabel 1). Komposisi $\mathrm{CaO}, \mathrm{Na}_{2} \mathrm{O}$, dan $\mathrm{K}_{2} \mathrm{O}>2 \%$ sedangkan $\mathrm{TiO}_{2}, \mathrm{P}_{2} \mathrm{O}_{5}$, dan $\mathrm{MnO}<1 \%$. Batuan induk terindikasi telah mengalami pelapukan tingkat rendah dengan mengacu pada kadar LOI sekitar $3 \%$. Kandungan $\mathrm{SiO}_{2}, \mathrm{CaO}$, dan $\mathrm{MnO}$ semakin menurun dari bawah hingga atas profil yang diteliti. Pada sisi lain, peningkatan signifikan ditunjukkan oleh jumlah $\mathrm{Al}_{2} \mathrm{O}_{3}$ dan $\mathrm{F}_{2} \mathrm{O}_{3} \mathrm{~T}$ seiring dengan tingkat pelapukan hingga mencapai 1,5-2 kali lipat dari komposisinya dalam batuan induk. Loss of Ignition (LOI) pada keempat horizon pelapukan berada dalam rentang yang sempit, yaitu $14,77 \%$ hingga $15,49 \%$. Kadar UTJ pada studi ini berada dalam tingkat menengah yaitu $91 \mathrm{ppm}$ (horizon soil) - 157 ppm (batuan induk).

Index of Lateritization (IOL) pada batuan induk $(24,10)$ naik secara drastis menjadi 35,80 pada horizon saprolit. Indeks ini terus menaik menuju horizon laterit bawah $(38,30)$ dan horizon laterit atas $(41,20)$, namun sedikit menurun pada horizon soil $(39,80)$. Peningkatan nilai IOL adalah implikasi dari pengurangan $\mathrm{SiO}_{2}$ relatif terhadap jumlah $\mathrm{Al}_{2} \mathrm{O}_{3}$ dan $\mathrm{Fe}_{2} \mathrm{O}_{3 \mathrm{~T}}$ (Babechuk dkk., 2014; Ohandja dkk., 2020). Sejumlah akar tetumbuhan yang dijumpai pada horizon soil bukan representasi dari $\mathrm{Al}_{2} \mathrm{O}_{3}$ maupun $\mathrm{Fe}_{2} \mathrm{O}_{3 \mathrm{~T}}$, namun merupakan bahan volatil. Kondisi tersebut dapat menjelaskan penurunan IOL yang disertai dengan kenaikan LOI pada horizon ini dibandingkan dengan horizon di bawahnya (Tabel 2). Perubahan rasio kelimpahan oksida utama dan UTJ keempat horizon pelapukan relatif terhadap batuan induk ditampilkan dalam bentuk grafis pada Gambar 4.

Tabel 1. Komposisi oksida utama, unsur jejak, UTJ, dan beberapa rasio pada studi di Puncak Mandeh

\begin{tabular}{llllll}
\hline & Batuan Induk & \multicolumn{1}{c}{ Saprolit } & Laterit bawah & Laterit atas & Soil \\
\hline $\mathrm{Oksida}^{2}$ utama $(\%)$ & & & & \\
$\mathrm{SiO}_{2}$ & 66,24 & 52,50 & 51,58 & 49,41 & 49,99 \\
$\mathrm{TiO}_{2}$ & 0,53 & 0,46 & 0,55 & 0,61 & 0,65 \\
$\mathrm{Al}_{2} \mathrm{O}_{3}$ & 15,77 & 25,20 & 22,58 & 23,83 & 22,93 \\
$\mathrm{Fe}_{2} \mathrm{O}_{3 \mathrm{~T}}$ & 5,24 & 4,57 & 9,47 & 10,84 & 10,08 \\
$\mathrm{MnO}$ & 0,09 & 0,03 & 0,01 & 0,01 & 0,02 \\
$\mathrm{CaO}$ & 2,64 & 0,01 & 0,02 & 0,01 & 0,02 \\
$\mathrm{MgO}$ & 1,01 & 0,14 & 0,14 & 0,14 & 0,15 \\
$\mathrm{Na} 2 \mathrm{O}$ & 3,08 & 0,01 & 0,01 & $<0,01$ & $<0,01$ \\
$\mathrm{~K} \mathrm{O}$ & 2,29 & 0,02 & 0,05 & 0,04 & 0,03 \\
$\mathrm{P} \mathrm{O}_{5}$ & 0,23 & 0,02 & 0,02 & 0,32 & 0,02 \\
$\mathrm{LOI}$ & 3,08 & 15,41 & 15,49 & 14,77 & 15,07 \\
\hline $\mathrm{Unsur} J e j a k$ & dan UTJ (ppm) & & & & \\
$\mathrm{Li}$ & 16,79 & 13,44 & 26,68 & 25,05 & 20,61 \\
$\mathrm{Sc}$ & 10,87 & 11,84 & 17,40 & 17,48 & 14,86 \\
$\mathrm{~V}$ & 54,41 & 37,04 & 65,51 & 88,43 & 84,74 \\
$\mathrm{Ga}$ & 17,58 & 24,96 & 33,53 & 36,72 & 34,37 \\
$\mathrm{Rb}$ & 56,86 & 1,98 & 3,13 & 3,05 & 2,48 \\
$\mathrm{Sr}$ & 237,80 & 1,50 & 21,51 & 15,84 & 7,69 \\
$\mathrm{Y}$ & 32,07 & 13,15 & 16,86 & 14,19 & 11,70 \\
$\mathrm{Nb}$ & 5,12 & 4,11 & 6,12 & 6,58 & 7,54 \\
$\mathrm{Ba}$ & 549,60 & 88,22 & 95,18 & 101,60 & 95,87 \\
$\mathrm{La}$ & 30,37 & 18,78 & 30,04 & 21,39 & 16,31 \\
$\mathrm{Ce}$ & 58,13 & 63,02 & 53,03 & 44,88 & 48,65 \\
$\mathrm{Pr}$ & 8,52 & 4,51 & 6,68 & 4,92 & 3,79 \\
$\mathrm{Nd}$ & 32,40 & 15,41 & 22,41 & 16,39 & 12,33 \\
& & & & &
\end{tabular}




\begin{tabular}{llllll}
\hline & Batuan Induk & Saprolit & Laterit bawah & Laterit atas & Soil \\
\hline Sm & 6,53 & 2,50 & 3,76 & 2,71 & 1,98 \\
Eu & 1,36 & 0,38 & 0,67 & 0,48 & 0,32 \\
Gd & 5,37 & 2,23 & 2,94 & 2,32 & 1,88 \\
Tb & 0,78 & 0,43 & 0,52 & 0,46 & 0,41 \\
Dy & 6,34 & 2,58 & 3,46 & 2,91 & 2,39 \\
Ho & 0,98 & 0,53 & 0,63 & 0,57 & 0,51 \\
Er & 2,71 & 1,26 & 1,69 & 1,44 & 1,19 \\
Tm & 0,32 & 0,24 & 0,26 & 0,25 & 0,23 \\
Yb & 3,31 & 1,57 & 2,26 & 1,89 & 1,51 \\
Lu & 0,31 & 0,23 & 0,26 & 0,25 & 0,23 \\
Ta & 0,70 & 0,69 & 0,71 & 0,72 & 0,71 \\
Th & 4,66 & 5,01 & 5,82 & 6,59 & 8,85 \\
U & 4,79 & 2,58 & 0,67 & 0,34 & 0,11 \\
IUTJ & 157,43 & 113,67 & 128,61 & 100,86 & 91,73 \\
\hline
\end{tabular}

Tabel 2. Index of Lateritization (IOL), anomali, dan rasio kimia dalam studi ini

\begin{tabular}{llllll}
\hline & Batuan Induk & Saprolit & Laterit bawah & Laterit atas & \multicolumn{1}{c}{ Soil } \\
\hline $\mathrm{IOL}$ & 24,10 & 35,80 & 38,30 & 41,20 & 39,80 \\
$\mathrm{Fe} / \mathrm{Sc}$ & 3374,43 & 2701,86 & 3809,77 & 4340,96 & 4748,32 \\
$\mathrm{Ce} / \mathrm{Ce}$ & 0,76 & 2,72 & 0,81 & 1,11 & 2,22 \\
$\mathrm{Eu} / \mathrm{Eu}$ & 0,31 & 0,12 & 0,17 & 0,16 & 0,13 \\
$(\mathrm{La} / \mathrm{Yb})_{\mathrm{N}}$ & 6,19 & 8,06 & 8,96 & 7,63 & 7,28 \\
$\mathrm{La} / \mathrm{Th}$ & 6,52 & 3,75 & 5,16 & 3,25 & 1,84 \\
$\mathrm{Sm} / \mathrm{Nd}$ & 0,20 & 0,16 & 0,17 & 0,17 & 0,16 \\
$\mathrm{Th} / \mathrm{U}$ & 0,97 & 1,94 & 8,69 & 19,38 & 80,45 \\
\hline
\end{tabular}

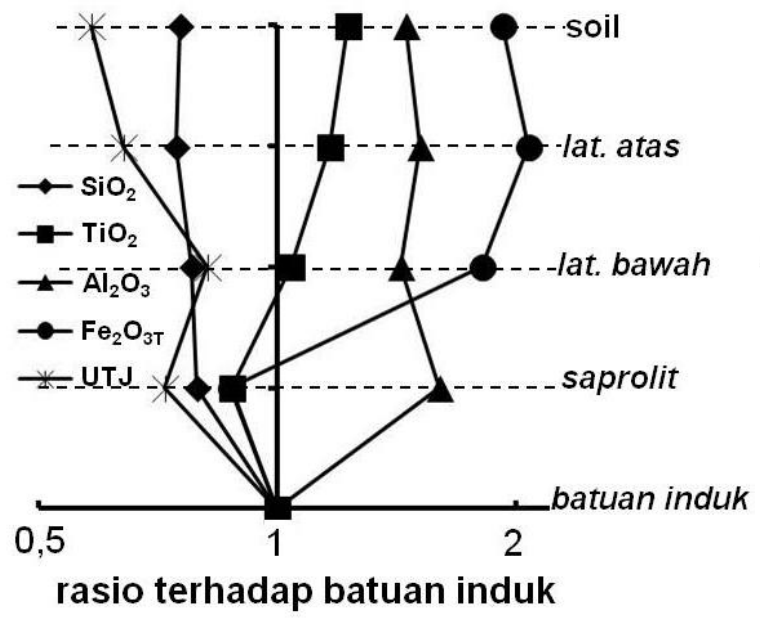

(a)

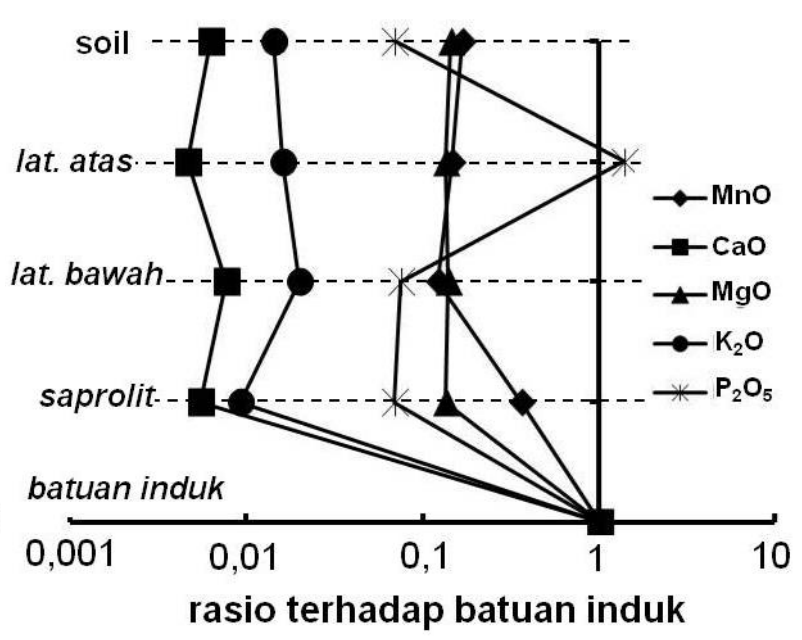

(b)

Gambar 4. Rasio kelimpahan oksida utama dan UTJ setiap horizon pelapukan terhadap batuan induk: a) $\mathrm{SiO}_{2}, \mathrm{TiO}_{2}, \mathrm{Al}_{2} \mathrm{O}_{3}, \mathrm{Fe}_{2} \mathrm{O}_{3}$, dan UTJ; dan b) $\mathrm{MnO}, \mathrm{CaO}, \mathrm{MgO}, \mathrm{K} 2 \mathrm{O}$, dan $\mathrm{P}_{2} \mathrm{O}_{5}$

\section{PEMBAHASAN}

\section{Proses Kaolinitisasi}

Mayoritas oksida utama pada horizon pelapukan adalah $\mathrm{SiO}_{2}, \mathrm{Al}_{2} \mathrm{O}_{3}$, dan $\mathrm{Fe}_{2} \mathrm{O}_{3} \mathrm{~T}$ dengan rerata $51,12 \%, 23,64 \%$, dan $8,74 \%$ secara berurutan. Diagram segitiga untuk membedakan jenis pelapukan berdasarkan kadar $\mathrm{SiO}_{2}, \mathrm{Al}_{2} \mathrm{O}_{3}$, dan $\mathrm{Fe}_{2} \mathrm{O}_{3}$ т. Berdasarkan diagram tersebut, seluruh sampel hasil pelapukan berada dalam bidang kaolinitisasi (Gambar 5a). Menggunakan perbandingan oksida yang sama, terdapat diagram segitiga lainnya untuk membedakan kaolinitisasi, feritisasi, dan bauksitisasi pada proses pelapukan. Pelapukan batuan pada profil yang dipelajari lebih mengarah ke kaolinitasasi 


\section{MAKALAH ILMIAH}

dari pada bauksitisasi maupun pengayaan besi sebagaimana terlihat pada Gambar 5b. Hanya horizon saprolit yang berkarakter bauxitic kaolinite karena berkadar alumina paling tinggi. Meskipun terjadi peningkatan, kadar alumina dan besi pada profil di sini masih lebih kecil dibandingkan dengan stockpile bauksit di Pulau Selayar (Irzon, 2018). Bahan yang telah lama tak terjual di wilayah Kepulauan Riau tersebut memiliki kandungan $\mathrm{Al}_{2} \mathrm{O}_{3}$ dan $\mathrm{Fe}_{2} \mathrm{O}_{3 \mathrm{~T}}$ masingmasing sebesar $37 \%$ dan $23,84 \%$, secara berurutan.
Pada tahap awal pelapukan, oksida alkali dan alkali tanah $\left(\mathrm{K}_{2} \mathrm{O}, \mathrm{Na}_{2} \mathrm{O}, \mathrm{CaO}\right.$, dan $\mathrm{MgO})$ mudah terlarut akibat reaksi mineral mudah lapuk dengan larutan asam yang dapat berasal dari air hujan (FernándezCaliani dan Cantano, 2010). Felspar dan mika, terutama biotit, disebut sebagai dua jenis mineral yang paling rentan terhadap kaolinitisasi dengan mekanisme yang telah dijabarkan oleh Fernandez-Caliani (2018) seperti pada persamaan 2-4 berikut ini:

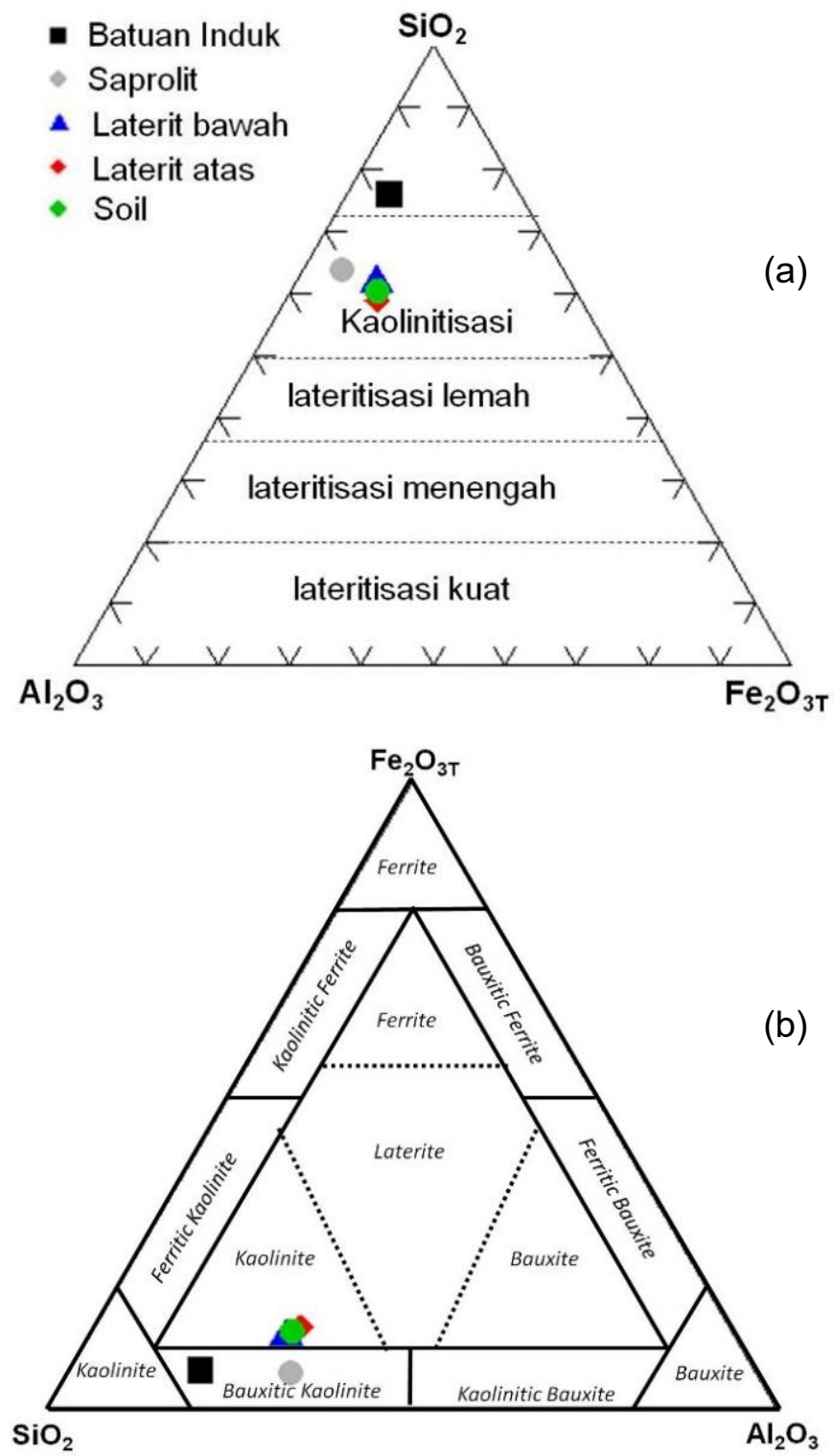

Gambar 5. Dua diagram segitiga komposisi $\mathrm{Al}_{2} \mathrm{O}_{3}-\mathrm{SiO}_{2}-\mathrm{Fe}_{2} \mathrm{O}_{3} \mathrm{~T}$ mengenai pelapukan:

a) Horizon pelapukan pada profil yang dipelajari dikategorikan mengalami kaolinitisasi; dan b) profil di Puncak Mandeh cenderung mengalami pengayaan kaolinit daripada bauksit maupun ferit (sumber Aleva (1994)) 


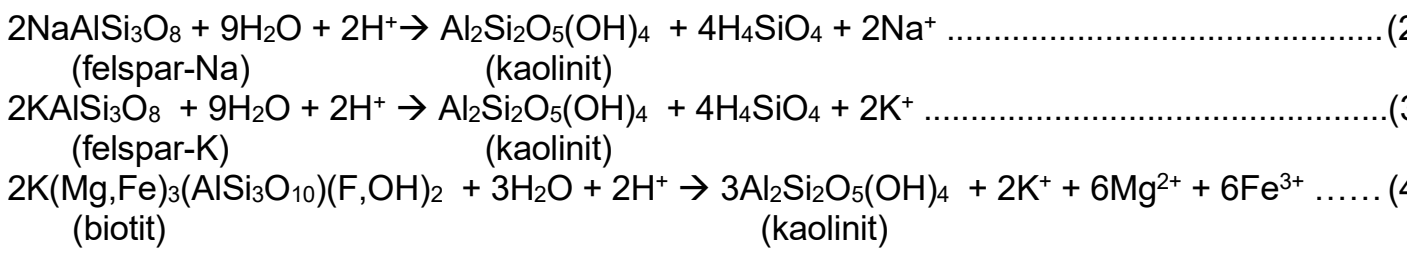

Material tersebut kemudian terbawa keluar dari profil pelapukan akibat proses hujan yang terus terjadi. Namun demikian, setelah dua jenis bahan tersebut telah keluar, maka sangat sedikit yang masih dapat termobilisasi ke tahap pelapukan selanjutnya. Hal ini menjelaskan penurunan drastis $\mathrm{K}_{2} \mathrm{O}, \mathrm{CaO}$, dan $\mathrm{MgO}$ dari batuan induk ke horizon saprolit namun dengan derajat perubahan yang relatif kecil pada horizon-horizon lain (Tabel 1).

Proses deferifikasi pada horizon saprolit terdeteksi berdasarkan karakter rasio $\mathrm{Fe} / \mathrm{Sc}$ (Fernandez-Caliani, 2010). Namun demikian, tiga horizon pelapukan lainnya justru mengalami pengayaan besi relatif terhadap batuan induk dan mencapai rasio puncak pada horizon soil (Tabel 1). Mineralmineral mafik seperti biotit dan amfibol banyak mengandung unsur Fe yang mudah terlepas akibat pelapukan seperti dijelaskan pada persamaan (4). Marfil and Maiza (2012) menyebutkan bahwa $\mathrm{Ti}$ mudah terlepas dari mineral primer pada batuan induk selama kaolinitisasi. Meskipun derajat mobilisasi $\mathrm{Fe}$ dan $\mathrm{Ti}$ lebih kecil dibandingkan dengan elemen alkali dan alkali tanah, keduanya mudah terserap sebagai oksida sekunder atau membentuk kompleks organomineral (dos Santos dkk., 2019). Kondisi tersebut membuat jumlah oksida Fe dan Ti yang terlepas pada tahap awal pelapukan (horizon saprolit) semakin meningkat pada horizon-horizon di atasnya. Kemudian, transfer kompleks organomineral yang terbentuk menuju atas profil pelapukan semakin baik akibat penyerapan oleh tetumbuhan.

Kecenderungan mobilisasi yang serupa dengan oksida alkali dan alkali tanah juga ditunjukkan oleh unsur Large Ion Lithophile
Elements (LILE) diantaranya $\mathrm{Rb}, \mathrm{Sr}, \mathrm{Ba}, \mathrm{Sc}$, and $\mathrm{U}$. Penurunan dratis terdeteksi pada $\mathrm{Rb}, \mathrm{Sr}$, dan $\mathrm{Ba}$ dengan konsentrasi masingmasing 56 ppm, 237 ppm, dan 549 ppm pada batuan induk menjadi $2 \mathrm{ppm}, 7 \mathrm{ppm}$, dan 95 ppm pada horizon soil. Lebih lanjut, Pierre dkk. (2016) menjelaskan bahwa penurunan jumlah $\mathrm{Ca}, \mathrm{Ba}$, dan $\mathrm{Sr}$ selama proses pelapukan dapat dipengaruhi oleh ketiadaan peran mineral karbonat maupun sulfat dalam pendistribusian kation. Jumlah uranium terus menurun pararel terhadap pelapukan dan bahkan hampir hilang dengan konsentrasi di horizon soil sebesar $0,11 \mathrm{ppm}$.

High Field Strength Elements (HFSE) seperti $\mathrm{Nb}, \mathrm{Ta}$, Th, dan $\mathrm{Ga}$ disebut kelompok unsur yang paling resisten terhadap pelapukan (Fernández-Caliani dan Cantano, 2010; Abedini dan Calagari, 2016; Ohandja dkk., 2020). Meski terdapat peningkatan kelimpahan kelompok HFSE ke arah atas profil pelapukan dan mencapai kadar tertinggi pada horizon laterit atas yang kaya besi, pengayaan ini tidak terlalu signifikan akibat immobilitas HFSE terhadap pelapukan. Afinitas oksida titanium terhadap $\mathrm{Nb}$ dan $\mathrm{Ta}$ ditunjukkan oleh koefisien korelasi positif kuat antara $\mathrm{TiO}_{2}-\mathrm{Nb}(0,98)$ maupun $\mathrm{TiO}_{2}$ - $\mathrm{Ta}(0,85)$ seperti pada Tabel 3. Jumlah Th berkorelasi positif terhadap tingkat pelapukan, sedangkan $U$ justru sebaliknya sehingga ratio $\mathrm{Th} / \mathrm{U}$ meningkat dari 0,97 pada batuan induk hingga 80,45 pada horizon soil (Tabel 2). Besar kemungkian bahwa Th pada profil ini terikat dengan oksida titanium berdasarkan kenaikan jumlah Th terhadap penambahan kadar Ti seperti dijelaskan pada pelapukan di barat daya Spanyol (Fernández-Caliani dan Cantano, 2010). 
Tabel 3. Beberapa koefisien korelasi yang penting pada studi kaolinitisasi di Puncak Mandeh

\begin{tabular}{|c|c|c|c|c|c|c|c|c|c|c|c|}
\hline & $\mathrm{SiO}_{2}$ & $\mathrm{TiO}_{2}$ & $\mathrm{Al}_{2} \mathrm{O}_{3}$ & $\mathrm{MnO}$ & $\mathrm{CaO}$ & $\mathrm{K}_{2} \mathrm{O}$ & $\mathrm{P}_{2} \mathrm{O}_{5}$ & $\sum$ UTJ & $\mathrm{Nb}$ & $\mathrm{Ta}$ & Th \\
\hline $\mathrm{SiO}_{2}$ & 1,00 & $-0,45$ & $-0,90$ & 0,99 & 0,97 & 0,97 & 0,96 & 0,90 & $-0,51$ & $-0,49$ & $-0,64$ \\
\hline $\mathrm{TiO}_{2}$ & & 1,00 & 0,06 & $-0,43$ & $-0,25$ & $-0,24$ & $-0,22$ & $-0,55$ & 0,98 & 0,85 & 0,87 \\
\hline $\mathrm{Al}_{2} \mathrm{O}_{3}$ & & & 1,00 & $-0,87$ & $-0,96$ & $-0,95$ & $-0,96$ & $-0,82$ & 0,10 & 0,10 & 0,35 \\
\hline $\mathrm{MnO}$ & & & & 1,00 & 0,97 & 0,97 & 0,96 & 0,82 & $-0,52$ & $-0,51$ & $-0,60$ \\
\hline $\mathrm{CaO}$ & & & & & 1,00 & 1,00 & 1,00 & 0,84 & $-0,33$ & $-0,29$ & $-0,51$ \\
\hline $\mathrm{K}_{2} \mathrm{O}$ & & & & & & 1,00 & 1,00 & 0,84 & $-0,32$ & $-0,29$ & $-0,51$ \\
\hline $\mathrm{P}_{2} \mathrm{O}_{5}$ & & & & & & & 1,00 & 0,83 & $-0,31$ & $-0,25$ & $-0,51$ \\
\hline$\Sigma$ UTJ & & & & & & & & 1,00 & $-0,55$ & $-0,40$ & $-0,79$ \\
\hline $\mathrm{Nb}$ & & & & & & & & & 1,00 & 0,83 & 0,89 \\
\hline $\mathrm{Ta}$ & & & & & & & & & & 1,00 & 0,56 \\
\hline Th & & & & & & & & & & & 1,00 \\
\hline
\end{tabular}

\section{Karakter UTJ}

Kadar UTJ pada penelitian ini telah dinormalilasi terhadap konsentrasi chondrite (Boynton, 1984) untuk menghilangkan efek Oddo-Harkins dan diplot ke dalam diagram laba-laba. Jumlah UTJ pada setiap sampel berada pada rentang 8 hingga 100 kali komposisi chondrite (Gambar 6a). Kemiringan curam dapat diperhatikan pada kenaikan nomor atom dari UTJ-ringan, sedangkan UTJ-berat cenderung landai. Hampir seluruh unsur pada grup UTJ berkarakter sama, diantaranya yaitu terdapat di alam dengan bilangan oksidasi +3 kecuali $\mathrm{Ce}$ dan $\mathrm{Eu}$. Cerium juga terdapat di alam dengan bilangan oksidasi +4 sedangkan Europium dengan valensi +2 . Oleh sebab itu, besaran anomali pada kedua unsur tersebut dijadikan petunjuk mengenai proses pembentukan batuan, korelasi antar batuan, alterasi, maupun pelapukan (Burnham dan Berry, 2014; Irzon dkk., 2020; Arianto dkk., 2020). Nilai anomali $\mathrm{Ce}\left(\mathrm{Ce} / \mathrm{Ce}^{*}\right)$ dan $\mathrm{Eu}$ $\left(\mathrm{Eu} / \mathrm{Eu}^{*}\right)$ dihitung berdasarkan persamaan (5) dan (6) berikut:

$\mathrm{Ce} / \mathrm{Ce}^{*}=\mathrm{Ce}_{\mathrm{N}}^{2} /\left(\mathrm{La}_{\mathrm{N}} \times \operatorname{Pr}_{\mathrm{N}}\right)$

$\mathrm{Eu} / \mathrm{Eu}^{*}=\mathrm{Eu}_{N}^{2} /\left(\mathrm{Sm}_{\mathrm{N}} \times \mathrm{Gd} \mathrm{d}_{\mathrm{N}}\right)$

$\mathrm{Ce}_{\mathrm{N}}, \mathrm{La}_{\mathrm{N}}, \operatorname{Pr}_{\mathrm{N}}, \mathrm{Eu}_{\mathrm{N}}, \mathrm{Sm}_{\mathrm{N}}$, dan $\mathrm{Gd}_{\mathrm{N}}$ adalah hasil normalisasi jumlah setiap elemen pada sampel terhadap konsentrasi chondrite
(Boynton, 1984). Ce/Ce* tampak beragam dalam rentang 0,76 (batuan induk) hingga 2,72 (saprolit). Pada sisi lain, Anomali Eu negatif terindikasi pada seluruh sampel pada kisaran $\mathrm{Eu} / \mathrm{Eu}^{*}$ dari 0,12 (horizon soil) sampai 0,31 (batuan induk).

Ce diketahui dapat terfraksionasi dari sesama UTJ lain selama proses pelapukan basal, granit, batuan metamorf, batuan sedimen, dan meteorit akibat perubahan dari $\mathrm{Ce}^{3+}$ menjadi $\mathrm{Ce}^{4+}$ (Yussof dkk., 2013; Irzon, 2018; Tohar dkk., 2020; Yaraghi dkk., 2020). Pada keempat horizon pelapukan, horizon laterit bawah memiliki konsentrasi UTJ yang paling tinggi. Namun demikian, kadar $\mathrm{Ce}$ tertinggi justru terdapat pada horizon saprolit. Hal ini dapat disebabkan oleh pembentukan $\mathrm{CeO}_{2}$ yang bersifat stabil dan tidak mobile pada horizon saprolit. Pada tahap pelapukan selanjutnya, ion-ion UTJ lain berpindah ke horizon diatasnya, sedangkan $\mathrm{Ce}^{4+}$ dalam bentuk $\mathrm{CeO}_{2}$ tetap tertinggal di horizon saprolit untuk menjelaskan variasi komposisi $\mathrm{Ce}$ pada profil yang dipelajari. Kerentanan mineral felspar pada tahap awal pelapukan dikonfirmasi oleh penurunan nilai $\mathrm{Eu} / \mathrm{Eu}^{*}$ secara drastis dari batuan induk menuju saprolit. Eu/Eu* tidak banyak berubah di empat horizon pelapukan karena sebagian besar felspar maupun mika telah lapuk di horizon saprolit (Bazilevskaya dkk., 2013; Abedini dan Calagari, 2016). 


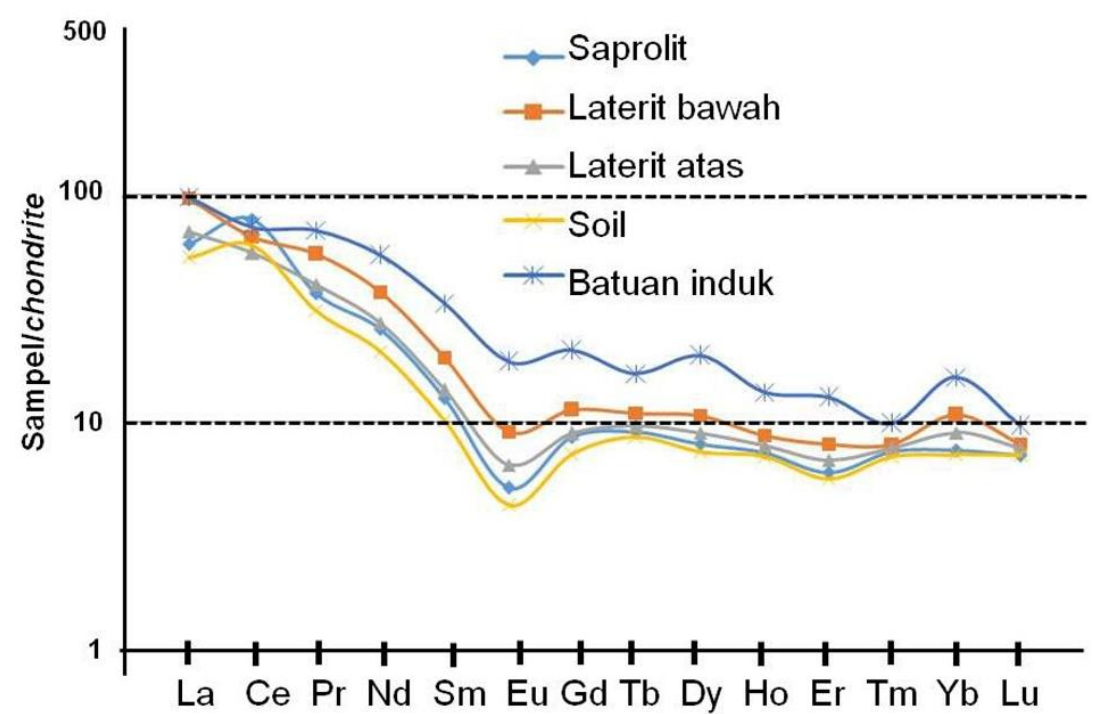

(a)

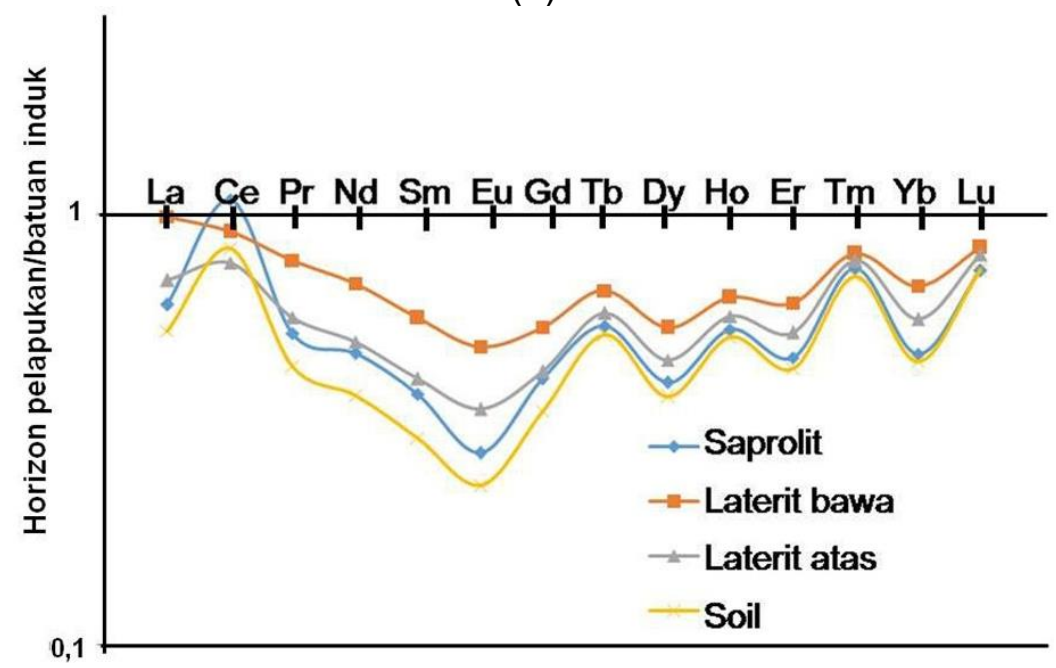

(b)

Gambar 6. Diagram laba-laba UTJ pada studi ini: a) konsentrasi pada setiap sampel dinormalisasi terhadap kadar chondrite; dan b) rasio komposisi setiap horizon pelapukan terhadap batuan induk

Pola yang mirip dapat diamati pada diagram normalisasi komposisi setiap horizon pelapukan terhadap batuan induk (Gambar 6b) untuk menekankan keseragaman derajat mobilitas UTJ. Hanya kandungan Ce pada saprolit lebih tinggi daripada batuan induk, sedangkan unsur lain pada horizon manapun terdeteksi lebih rendah. Deret $\mathrm{Nd}$ hingga Gd tampak mengalami penurunan kadar paling berat pada setiap horizon pelapukan. Terdapat korelasi positif kuat antara kadar UTJ terhadap $\mathrm{SiO}_{2}$ dengan koefisien korelasi $(r) 0,90, \mathrm{MnO}(r=0,82)$, $\mathrm{CaO}(r=0,84), \mathrm{K}_{2} \mathrm{O}(r=0,84)$, dan $\mathrm{P}_{2} \mathrm{O}_{5}$ $(0,83)$ seperti dapat dilihat pada Tabel 3. Berdasarkan korelasi tersebut terdapat kemungkinan bahwa apatit $\left(\mathrm{Ca}_{5}\left(\mathrm{PO}_{4}\right)_{3}(\mathrm{~F}, \mathrm{Cl}, \mathrm{OH})\right)$ merupakan mineral yang berasosiasi dengan UTJ pada pelapukan di Puncak Mandeh. Pada sisi lain, kecil kemungkinan bahwa UTJ di sini berasosiasi dengan monasit berdasarkan berkorelasi negatif jumlah UTJ terhadap Th dan Al dengan koefisein korelasi -0,79 dan 0,82 secara berurutan (Tabel 3 ). Kesimpulan ini dapat dikonfirmasi melalui studi petrografi pada masa mendatang.

Beberapa rasio yang melibatkan elemen UTJ banyak dimanfaatkan dalam studi pelapukan, seperti $(\mathrm{La} / \mathrm{Yb})_{\mathrm{N}}, \mathrm{La} / \mathrm{Th}$, dan $\mathrm{Sm} / \mathrm{Nd}$. Ukuran fraksionasi UTJ sebagai 
indikasi pemisahan antara UTJ-ringan dan UTJ-berat selama proses geokimia dihitung berdasarkan rasio (La/Yb) $)_{\mathrm{N}}$ (Su dkk., 2017; Yussof dkk., 2019; Ohandja dkk., 2020; Yaraghi dkk., 2020). Meskipun dalam rentang yang sempit, proses pelapukan di Puncak Mandeh meningkatkan derajat fraksionasi UTJ $\left((\mathrm{La} / \mathrm{Yb})_{\mathrm{N}}=6,19\right)$ pada batuan induk hingga mencapai maksimal pada horizon laterit bawah $\left((\mathrm{La} / \mathrm{Yb})_{N}=8,96\right)$ seperti tercantum pada Tabel 2. Peningkatan rasio tersebut menunjukkan presipitasi UTJ-ringan yang lebih baik selama proses pelapukan dibandingkan dengan UTJ-berat. Kecuali pada batuan induk, ratio La/Th $(1,84$ - 3,75) maupun $\mathrm{Sm} / \mathrm{Nd}(0,16-0,20)$ relatif konstan di keempat horizon pelapukan. Konsistensi tersebut bermakna bahwa meski telah terjadi fraksionasi UTJ pada keempat horizon pelapukan, perubahan jumlahnya tidak substansial (Sahoo dkk., 2017).

\section{KESIMPULAN}

Batuan gunungapi di daerah penelitian telah mengalami proses kaolinitisasi akibat pelapukan. Meskipun kadar alumina dan besi mengalami peningkatan akibat pelapukan, jumlahnya belum berkategori ekonomis. Kaolinitasi berasosiasi dengan penurunan drastis kelimpahan $\mathrm{K}_{2} \mathrm{O}, \mathrm{CaO}$, dan $\mathrm{MgO}$ dari batuan induk ke horizon saprolit tetapi dengan derajat perubahan yang relatif minimum pada horizon-horizon lain. Proses ini kemungkinan besar terjadi akibat perubahan feldspar dan mika. Diagram normalisasi konsentrasi UTJ menunjukkan pola yang serupa, yaitu penurunan curam pada UTJ-rendah dan cenderung lebih landai pada UTJ-berat. Tidak terdapat pengayaan UTJ pada horizon pelapukan tertentu pada profil yang diteliti. Pembentukan $\mathrm{Ce}^{4+}$ membuat beberapa bagian dari Ce tertinggal pada horizon saprolit. Kondisi ini mengakibatkan derajat mobilisasi $\mathrm{Ce}$ menuju horizon pelapukan selanjutnya berbeda dengan UTJ lain. Pelapukan felspar-mika dan dugaan apatit sebagai mineral yang berasosiasi terhadap UTJ dapat dijelaskan melalui analisis mikroskopis pada masa mendatang.

\section{UCAPAN TERIMA KASIH}

Penulis ingin mengucapkan terimakasih kepada Kepala Pusat Survei Geologi atas izin penggunaan data dalam studi ini. Dana penelitian ini berasal dari kegiatan eksplorasi UTJ Bidang Geosains Pusat Survei Geologi di wilayah Sumatra Barat. Bapak Joko Subandrio telah memberi banyak masukan mengenai penggunaan data geokimia. Terimakasih atas asistensi Ibu Irfanny Agustiani, Ibu Erna, Ibu Indah, dan Ibu Citra dalam analisis laboratorium.

\section{DAFTAR PUSTAKA}

Abedini, A. and Calagari, A. A., 2016. Geochemical characteristics of the Arabshah kaolin deposit, Takab geothermal field, NW Iran. Arabian Journal of Geosciences, 9(9), 548.

Alam, S. Sunarminto, B. H. and Siradz, S.A., 2012. Karakteristik bahan induk tanah dari formasi geologi kompleks ultramafik di Sulawesi Tenggara. Jurnal Agroteknos, 2(2), hal. 112-120.

Aleva, G.J.J., 1994. Laterites: Concepts, Geology, Morphology and Chemistry. Wageningen, Netherlands: International Soil Reference and Information Centre (ISRIC).

Arianto, Sosidi, H. Prismawiryanti dan Pusptasari, D.J., 2020. Pemisahan Logam Tanah Jarang dari Limbah (Tailing) Emas Poboya dengan Metode Pengendapan. KOVALEN: Jurnal Riset Kimia, 6(1), hal.9-17.

Babechuk M.G., Widdowson M., and Kamber B.S. 2014. Quantifying chemical weathering intensity and trace element release from two contrasting basalt profiles, Deccan Traps, India. Chem Geol 363, p.5675.

Bazilevskaya, E., Lebedeva, M., Pavich, M., Rother, G., Parkinson, D. Y., Cole, D., and Brantley, S. L., 2013. Where fast weathering creates thin regolith and slow weathering creates thick regolith. Earth Surface Processes and Landforms, 38(8), p.847-858. 
Boynton, W.V. (1984). Cosmochemistry of the rare earth elements: meteorite studies. Developments in Geochemistry, 2, 63-114, 1984.

Burnham, A.D. and Berry, A.J., 2014. The effect of oxygen fugacity, melt composition, temperature and pressure on the oxidation state of cerium in silicate melts. Chemical Geology, 366, p.52-60.

Du, X., Rate, A.W. and Gee, M.M., 2012. Redistribution and mobilization of titanium, zirconium and thorium in an intensely weathered lateritic profile in Western Australia. Chemical Geology, 330, p.101-115.

dos Santos, J.C.B., Le Pera, E., de Oliveira, C.S., de Souza Júnior, V.S., de Araújo Pedron, F., Corrêa, M.M. and de Azevedo, A.C., 2019. Impact of weathering on REE distribution in soil-saprolite profiles developed on orthogneisses in Borborema Province, NE Brazil. Geoderma, 347, p.103-117.

Fernández-Caliani, J.C. and Cantano, M., 2010. Intensive kaolinization during a lateritic weathering event in SouthWest Spain: mineralogical and geochemical inferences from a relict paleosol. Catena, 80(1), p.23-33.

Fernández-Caliani, J.C., 2018. Rare-earth element and stable isotope signatures of kaolin from a Pliocene lateritic weathering profile at midlatitude region (Andalusia, Spain): Implications for paleoweathering and paleoclimatic reconstructions. Catena, 167, p.160-170.

Garzanti, E., Padoan, M., Setti, M., LópezGalindo, A. and Villa, I.M., 2014. Provenance versus weathering control on the composition of tropical river mud (southern Africa). Chemical Geology, 366, p.61-74.

Handoko, A.D. and Sanjaya, E., 2018, February. Characteristics and genesis of Rare Earth Element (REE) in western Indonesia. In IOP Conf. Ser. Earth Environ. Sci. (Vol. 118, p. 012077).
Irzon, R., Syafri, I., Hutabarat, J. and Sendjaja, P., 2016. REE Comparison Between Muncung Granite Samples and their Weathering Products, Lingga Regency, Riau Islands. Indonesian Journal on Geoscience, 3(3), p.149-161.

Irzon, R., 2017. Pengayaan Logam Berat $\mathrm{Mn}, \mathrm{Co}$, dan Cr pada Laterit Nikel di Kabupaten Konawe Utara, Provinsi Sulawesi Tenggara. Buletin Sumber Daya Geologi, 12(2), p.71-86.

Irzon, R., 2018. Limbah Pencucian Bauksit Sebagai Sumber Unsur Tanah Jarang Potensial; Studi Kasus Pulau Selayar, Provinsi Kepulauan Riau. Buletin Sumber Daya Geologi, 13(1), hal. 45-57.

Irzon, R. and Abdullah, B., 2018. Element Mobilization During Weathering Process of Ultramafic Complex in North Konawe Regency, Southeast Sulawesi Based on A Profile from Asera. Indonesian Journal on Geoscience, 5(3), p.277-290.

Irzon, R., Syafri, I., Hutabarat, J., Sendjaja, P. and Permanadewi, S., 2018. Heavy metals content and pollution in tin tailings from Singkep Island, Riau, Indonesia. Sains Malaysiana, 47(11), p.2609-2616.

Irzon, R., Syafri, I., Ghani, A. A., Prabowo, A., Hutabarat, J. and Sendjaja, P., 2020. Petrography and geochemistry of the Pinkish Lagoi Granite, Bintan Island: Implication to magmatic differentiation, classification, and tectonic history. Bulletin of the Geological Society of Malaysia, 69, p.27-37.

Irvani, I., 2017. Bentang Alam dan Pelapukan Batuan Beku Granit pada Lokasi Tapak PLTN di Teluk Inggris dan Sekitarnya Kabupaten Bangka Barat. In Proceedings of National Colloquium Research and Community Service (vol. 1, 5 p).

Labus, M. and Bochen J., 2012. Sandstone degradation: an experimental study of accelerated weathering. Environ Earth Sci, 67, p.2027-2042. 
Liu, S., Suardi, I., Zheng, M., Yang, D., Huang, X. and Tong, P., 2019. Slab morphology beneath northern Sumatra revealed by regional and teleseismic traveltime tomography. Journal of Geophysical Research: Solid Earth, 124(10), p.10544-10564.

Marfil, S. and Maiza, P., 2012. Geochemistry of hydrothermal alteration in volcanic rocks. Geochemistry-Earth's System Processes, pp.39-60.

Meshram, R., Bhondwe, A., Jawadand, S, Raut, T., Dandekar, S., Joshi, V. and Randive, K., 2019. Formation of Lateritic Kaolin Deposit over Hoskote-Kolar Granodiorite: A Case Study from Nandigudi and Bavanhalli Localities, Kolar District, Karnataka. Journal of Applied Geochemistry, 21(2), p.201-211.

Metcalfe I., 2017, Tectonic evolution of Sundaland, Bulletin of the Geological Society of Malaysia, 63, p.27 - 60 .

Ohandja, H.N., Onana, V.L., Tang, S.D.N., Ze, A.N.O. and Ekodeck, G. E., 2020. Behavior of major, trace, and rare earth elements in an atypical lateritic profile overlying micaceous quartzites, Centre Cameroon: imprint of the parent rock structure. Arabian Journal of Geosciences, 13(17), p.116.

Permanajadi, I., Zakaria, Z., Hadian, M.S.D., Anwar, H.Z., dan Setijadi, E., 2018. Kajian Petrografi pada Zona Pelapukan Breksi Piroklastik terhadap Longsoran Gunung Pawinihan, Kabupaten Banjarnegara, Provinsi Jawa Tengah. Dinamika Rekayasa, 14(1), p.9-16.

Pierre, C., Blanc-Valleron, M.M., Caquineau, S., März, C., Ravelo, A.C., Takahashi, K. and Zarikian, C.A., 2016. Mineralogical, geochemical and isotopic characterization of authigenic carbonates from the methanebearing sediments of the Bering Sea continental margin (IODP Expedition 323, Sites U1343-U1345). Deep Sea
Research Part II: Topical Studies in Oceanography, 125, p. 133-144.

Rosidi, H.M.D., Tjokrosapoetro, S., Pendowo, B., Gafoer S. dan Suharsono, 1996. Peta Geologi Lembar Painan dan Bagian Timurlaut Lembar Muarasiberut, Sumatera, skala 1: 250.000. Pusat Penelitian dan Pengembangan Geologi, Bandung.

Sahoo, P.K., Guimarães, J.T.F., SouzaFilho, P.W.M., da Silva, M.S., Júnior, W.N., Powell, M.A., ... \& Costa, V.E., 2017. Geochemical characterization of the largest upland lake of the Brazilian Amazonia: Impact of provenance and processes. Journal of South American Earth Sciences, 80, p.541-558.

Sanematsu, K., Kon, Y. and Imai, A., 2015. Influence of phosphate on mobility and adsorption of REEs during weathering of granites in Thailand. Journal of Asian Earth Sciences, 111, p.14-30.

Su, N., Yang, S., Guo, Y., Yue, W., Wang, X., Yin, P. and Huang, X., 2017. Revisit of rare earth element fractionation during chemical weathering and river sediment transport. Geochemistry,

Geophysics, Geosystems, 18(3), p.935-955.

Tohar, S.Z. and Yunus, M.M., 2020. Mineralogy and BCR sequential leaching of ion-adsorption type REE: A novelty study at Johor, Malaysia. Physics and Chemistry of the Earth, Parts A/B/C, 102947.

Tupaz, C.A.J., Watanabe, Y., Sanematsu, K., Echigo, T., Arcilla, C. and Ferrer, C., 2020. Ni-Co Mineralization in the Intex Laterite Deposit, Mindoro, Philippines. Minerals, 10(7), 579.

Yaraghi, A., Ariffin, K.S. and Baharun, N., 2020. Comparison of characteristics and geochemical behaviors of REEs in two weathered granitic profiles generated from metamictized bedrocks in Western Peninsular Malaysia. Journal of Asian Earth Sciences, 104385. 


\section{MAKALAH ILMIAH}

Yusoff, Z.M., Ngwenya, B.T. and Parsons, I., 2013. Mobility and fractionation of REEs during deep weathering of geochemically contrasting granites in a tropical setting, Malaysia. Chemical Geology, 349, p.71-86.
Zulkarnain, I. (2016). Sumatra is not a Homogeneous Segment of Gondwana Derived Continental Blocks: A New Sight based on Geochemical Signatures of Pasaman Volcanic in West Sumatera. RISET Geologi dan Pertambangan, 26(1), p.1-13.

$\begin{array}{ll}\text { Diterima } & : \text { 3 November } 2020 \\ \text { Direvisi } & : \text { 23 Januari } 2021 \\ \text { Disetujui } & : \text { 31 Mei 2021 }\end{array}$

